\title{
New Geopolitical Role of Central Asia within Foreign Policy Interests of World Powers
}

\author{
Rustem Kulnazarov ${ }^{1}$ \\ ${ }^{1}$ Academy of Public Administration under the President of the Republic of Kazakhstan, Kazakhstan \\ Cprrespondence: Academy of Public Administration under the President of the Republic of Kazakhstan, 010000 \\ Astana, Abai str. 33A, Kazakhstan. Tel: 77-01-757-9408. E-mail: Kulnazarov@inbox.ru
}

Received: November 15, 2014

Accepted: January 20, 2015 Online Published: April 30, 2015

doi:10.5539/ass.v1 $1 \mathrm{n} 12 \mathrm{p} 125$

URL: http://dx.doi.org/10.5539/ass.v11n12p125

\begin{abstract}
As a result of the fall of the Soviet Union, the leading global and regional players have started their occupation of the geopolitical and geo-economical vacuum in Central Asia. This article is targeted to trace the competition growth with regard to establishment of control over the Central Asian region by global players, in particular, by Russia, seeking to return Central Asia, and China, striving to entangle the region into its orbit of influence. Within two post-Soviet decades, the world players still have not managed to develop a general cooperation scheme against each other in Central Asia. Although, at the beginning of the XXI century, Russia and China attempted to build up a scheme of the Russian-Chinese-Central Asian cooperation within the Shanghai Cooperation Organization, however this scheme cannot be called effective due to the absence of common vision of long-term interests in Russia, China and Central Asian countries. As it seems, even at very short by historical standards period of time, after the fall of the Soviet Union we observe clear interests in the Central Asian's policies of Russia and China.
\end{abstract}

Keywords: Central Asia, geopolitics, Russian foreign policy, Chinese foreign policy, Eurasian Union, Shanghai Cooperation Organization

\section{Introduction}

Historically, the region of Central Asia, due to its geographical position from ancient times, has played a significant role in international relations. Considering the fact that a substantive section of the Great Silk Road since the II century B.C. crossed the Region linking the East and the West, the Central Asia saw a very active development of political, trade and cultural relations. Through millenniums, the Region has demonstrated an active development in science, conducting large-scale commercial transactions, conclusion of diplomatic and military alliances.

For the whole period of the Great Silk Road from the II century B.C. to the XV century A.D., interests of various states such as China, Persia, Turkic Kaganate, Mongol Empire, Golden Horde and Tamerlane's Empire were intertwining in Central Asia.

In the XV-XVI centuries, along with strengthening of the Russian nation, Moscow had started to establish trade and diplomatic contacts with countries located in Central Asia.

In particular, the relations were actively developing between Moscow and the Kazakh Khanate. The roots of the Kazakh-Russian relations have a long-standing history. The relations became deeper after joining the Kazan (1552), Astrakhan (1556) khanates and peoples of the Volga region to Russia. The Russian state was interested in relations with the Kazakh Khanate with a view to ensure safety of traditional roads crossing the Kazakh Khanate and leading to Central Asia. In turn, the Kazakh Khanate was seeking an ally in Russia to struggle with the Central Asian khanates and Dzhungars. The Russian Empire gradually increasing its expansion in Central Asia considered Central Asia as a region where it could get cotton and access to the Indian Ocean.

The beginning of the rivalry between the British and Russian empires in Central Asia can be considered to be in 1819 , with the opening of the Russian mission in Khiva and in 1820, with the opening of the British mission in Bukhara. The rivalry existed until 1907 when the Anglo-Russian agreement was signed fixing the boundaries and areas of influence. Russia obtained a strong presence in Central Asia while the British Empire secured its land in India from Russian expansion. Afghanistan, by mutual consent, became a buffer country dividing the 
areas of influence. The XVIII century saw the final accession of Kazakh zhuzes to the tsarist Russia but it was hardly voluntarily. National-liberation uprisings repeatedly burst out in Kazakh steppe but were brutally crushed by punitive forces. Ashgabat, Bukhara Emirate, Khiva and Kokand Khanates were conquered in the second half of the XIX century.

With the entry to the Russian Empire and later to the Soviet Union, peoples of Central Asia entered a new development stage. However, due to super-centralized control from Moscow and closed regime, peoples of Central Asia have become hermetically isolated from their southern neighbors with whom they share extreme antique economic, spiritual and cultural ties.

\section{Method}

The methodological bases of this work are both general and special methods of scientific research. The use of these methods allowed to explore the nature of analyzed geopolitical interests of world powers in the region of Central Asia. Using the special methods of scientific research methodology of political science, such as content analysis, event analysis and comparative approach it was made an attempt to identify the causal relationship between the geopolitical interests of world powers and their policies in the region of Central Asia. The predictive analytics also had the methodological significance for disclosure the topic.

\section{Results}

Upon taking office by Vladimir Putin in 2000, the policy of Russia has been aimed at comprehensive strengthening of its international position. The Russian basic targets in Central Asia include a return of the region to the Russian geopolitical space, playing a key role in ensuring safety in the region and weakening invasion of foreign capital into the economy of the region and influence of other global countries specifically Islamic states. Central Asia is considered by Russia as a zone of geopolitical interests, separating it from many hazardous "hot spots" in the Middle East and South Asia.

Russia has its own economic interests in Central Asia striving to maintain rather capacious and geographically close market for export of Russian industrial products. The region plays a very important role as a traditional supplier of unique natural resources and non-ferrous metal products. Huge reserves of oil and gas in Kazakhstan, Turkmenistan and Uzbekistan are the essential factor that attracts attention of all world powers including the Russian Federation. Russia as a major exporter of gas to Europe and with economy which is basically built on the export of energy resources is not interested in competing in transportation of energy resources from Central Asia to Europe and global markets bypassing its territory. All these factors required a close encounter both in political and economic terms of Central Asian countries and Russia.

Establishment of the Eurasian Economic Community in 2000 was the practical implementation of the policy where Kazakhstan, Kyrgyzstan and Tajikistan are the members in addition to Russia and Belarus. The Community is basically aimed at the effective promotion by its member countries of the process of forming the Customs Union and the Single Economic Area as well as deepening of integration in economic and humanitarian areas (2013).

Since 2006, we can observe the intensification of interstate relations when the Interstate Council of the Eurasian Economic Community resolved to establish the Customs Union composed of Belarus, Russia and Kazakhstan. In 2007, the agreement for establishment of the single customs area and the Customs Union was signed in Dushanbe whereunder the Russia, Kazakhstan and Belarus undertook a commitment to establish the Customs Union (2007). In 2009, the informal summit in Almaty approved the Action Plan for 2010-2011 for the establishment of the Single Economic Area of three countries. In 2010, Russia, Belarus and Kazakhstan signed the agreement to establish the Single Economic Area. The same year, in December, the summit of the Eurasian Economic Community in Moscow reached agreement to establish the Eurasian Union on the basis of the Single Economic Area composed of Belarus, Kazakhstan and Russia (2010). The expansion of the future Eurasian Economic Union through the entry of new member states is quite a realistic prospect since Kyrgyzstan made a formal petition for entering as well as Tajikistan is involved in preparatory activities.

We may see the highlighted key points, vision of problems and prospects for further development of integration processes within the Eurasian Union in publications of the Presidents of three countries. So Nursultan Nazarbayev, President of the Republic of Kazakhstan in his publications "Eurasian Union: Ideas, Practice, Perspective, 1994-1997" and "Eurasian Union: From an Idea to the History of the Future" highlights that "economic interests, rather than abstract geopolitical slogans are the core engine of integration processes" (Nazarbayev, 2011; 1997). Alexander Lukashenko, President of the Republic of Belarus in his publication "Fate of Our Integration" considers the political future of the Eurasian Union as a "counterweight to the crisis", as "a 
right step to stable peace ... through establishment of defensive alliances" (Lukashenko, 2011). Vladimir Putin, President of the Russian Federation in the article "A New Integration Project for Eurasia - a Future Born Today" says that "construction of the Customs Union and the Single Economic Area creates a foundation for establishment of the Eurasian Economic Union in the future... we do not stop on this and set an ambitious goal: enter the next higher level of integration - the Eurasian Union" (Putin, 2011).

Therefore, the announcement by Putin in September 2011 of the course towards the Eurasian Union means that inconsistency of the Russian foreign policy comes to an end. And, consequently, the era of "multi-vector" in foreign policy orientation of many countries of the region comes to an end (Laumulin, 2012).

China with its intensively developing economy could not draw its attention to the Central Asian region by virtue of many reasons. Since 1993, China became a net importer of oil and is more and more challenged with needs for energy resources by virtue of its high economic growth. With a view to resolve the problem, China, along with development of its major three deposits in Xinjiang Uygur Autonomous Region and continental shelf in the South China Sea, has been actively involved in implementation of major projects in countries of the Persian Gulf, Papua New Guinea, Sudan, Thailand, Canada and now in Kazakhstan. Therefore, the region of Central Asia holds a prominent place in Chinese plans to diversify energy sources. Upon construction of oil and gas pipelines from this energy-rich region to China, the importance of Central Asia to China increased dramatically.

Another reason why China expressed a special interest to Central Asia after the fall of the USSR included the preservation of stability in the region, prevention of Islamic radicalism since the region borders to Xinjiang populated at that time by peoples of Turkic origination and practicing the Islam. China along with the implementation of the systematic program for resettlement of ethnic Han Chinese to the eastern province signed agreements seeking support in fight against "ethnic separatism" with countries of Central Asian and Russia.

We should also mention the transportation and logistics opportunities of Central Asia through which Chinese products today are delivered not only to markets of Central Asia but further to Russia, countries of the Middle East and Europe. In parallel, the network was created ensuring the supply of energy resources from Central Asia to China.

China is interested in preservation of geopolitical balance in the region of Central Asia. Since 1997, Chinese conceptual documents with regard to foreign policy are considering Central Asia as a "strategic rear" of China. Under this concept, the targets of Chinese policies in the region are formulated in the context of achieving two goals. On the one hand, keeping Central Asia as a region composed of "small divided countries and non-threatening to China" "buffer space" between China and Russia, on the other hand - preventing the emergence of a "dominant country" in Central Asia capable to get other countries of the region under its sole control (Syroezhkin, 2013).

In this regard, the establishment of the Eurasian Union is considered by China as a serious challenge to China, comparable to challenge of the Soviet time. Currently, China through the SCO has raised the level of influence, and if the idea of Putin is realized, the SCO will be inevitably weakened and may even disappear. It does not meet strategic interests of China for control and stabilization of Asia. China considers the Eurasian Union solely as a geopolitical project aimed at reanimation of the former Soviet Union for the purpose of economic and political containment and counterstand to China and non-regional powers.

The United States of America which in 90s was actively supporting the establishment of new independent states of the former Soviet Union, initially demonstrated interest to Central Asia with a view to strengthen its statehood, gave an active economic support, were interested in the region with heavy reserves of energy resources. September 11, 2001 became a new stage in revitalization of the role of Central Asia for USA. This region has become a basis for transit of troops, innocent goods from the USA, NATO member countries to Afghanistan. At the present, due to troop pullout from Afghanistan, the USA desires to use the economic potential of the region for recovery of post-war Afghanistan. The USA proposes the project of the Great Central Asia and Great Silk Road where under it is offered to include Afghanistan to economic relations of the region.

The USA considered to establish the Shanghai Group in 1996 basically as a Chinese initiative to strengthen relations with its western neighbors and to expand its influence in Central Asia to the detriment of Russia. Therefore, Washington did not considered the establishment of the Shanghai Group as a direct threat to its own interests in the region. However, the establishment of the SCO in 2001 caused more anxiety reactions in the USA since the Organization is considered as a new round of political rapprochement between Russia and China (Troush, 2006). 
Large-scale Chinese-Russian military training exercises in Shandong province in July 2005 (Peace Mission 2005) under the auspices of the SCO also raised concerns of many American observers. These exercises were intended to demonstrate the growing might of the People's Liberation Army of China as well as concerted actions of China and Russia in prevention of any "color revolutions" (Wishnick, 2005).

Evolution of rapprochement between Russia and China including in the framework of the SCO convinced most American liberal analysts to respond adequately. For example, Ted Carpenter, Director of the Libertarian Cato Institute said in 2006: "Until now, the United States was too careless with regard to the Russian-Chinese rapprochement" (Pan, 2006).

Since 2005, US analysts started to be concerned of two opposite trends: first, the intention of Russia to regain its influence in Central Asia, and secondly, China's ambitions to use the SCO as a lever to increase its influence in the region.

Russian factor still plays a great importance in relations of the United States with Central Asian countries. According to Jim Nicola, an expert on Russia and Central Asia of the US Congressional Research Service who was published in a 2007 report, the main concern of Washington regarding the Central Asian countries is their potential to stay really as independent states in particular in relation to Moscow:

"Actually all US analysts agree that Russia's actions should be clearly monitored in order to ensure that the independence of the Central Asian countries is not in danger" (Nichol, 2007).

At the same time, the report indicates that the US is concerned about the growth of anti-Americanism in Central Asia:

"In recent times Russia has activated its efforts against US influence in Central Asia, stimulating the Central Asian countries to develop economic and strategic relations with Russia and limit such ties with the United States" (Wishnick, 2005).

The European Union has initially pursued an active policy to establish trade and economic relations with the region and by far is the largest trading partner of most countries in the region. The EU's policy towards the countries of Central Asia in the 90's had differed by prevalence in relation to rhetoric of human rights, democratization of political regimes. Later, however, this policy was replaced by a different tactic. Since the EU pursues the policy of diversification of energy supplies, the region of Central Asia is very important in terms of participation in production and transportation of raw materials to Europe bypassing the Russia, which sets the tone in supply of energy to Europe. The EU understands that Russia and China do not make such demands to current regimes in Central Asia and yet successfully cooperates with them in order to implement their pragmatic interests. The EU therefore diminished its idealistic views on democratization and human rights in favor of their pragmatic interests.

The European Union also, like USA, closely monitors the growing political convergence between Russia and China in Central Asia, especially after Andijan events in May 2005. The Europeans consider a similarity of positions of two powers in Central Asia as one of factors of interest revival of Russia to the SCO.

Nevertheless, the majority of European experts as a rule emphasizes the limits of such bilateral cooperation and multilateral solidarity within the SCO.

So, for example Professor Niklas Norling from Swedish University of Uppsala emphasizes the differing interests of Beijing and Moscow in energy sector of Central Asia as well as "civilizational" perspective (Norling, 2007).

Mr. Bobo Lo from Royal Institute of International Affairs in London and Frank Umbach from German Society for Foreign Policy in Berlin also point at the Chinese growing need to import oil and gas from Central Asia as a source of friction with Russia (Lo, 2004).

Another barrier to spread the influence of China in Central Asia includes the existing control by Russia over the system of oil and gas pipelines in the region and export infrastructure. Despite the existing pipeline projects of Beijing, Moscow still has a prominent position in this sector and in the nearest future it will be difficult to compete with such position. This basic reality also has an impact on Chinese-Russian relations in Central Asia.

\section{Discussion}

Upon the fall of the Soviet Union, the Central Asia again became the focus of geopolitical interests of world powers. If in early XIX and XX centuries, the Russian and British empires were the major competing forces in the region, now we observe the intertwined interests of various global players, in particular such global powers as the Russian Federation and China which have long borders with Central Asian countries. 
With adoption by Russia, Ukraine and Belarus in Bialowieza Forest of the Decree dated 8 December 1991 for liquidation of the Soviet Union and establishment of new independent states, Central Asia has faced a geopolitical vacuum which sooner or later had to be occupied. At the same time, the region is still considered by other powers as the zone of geopolitical influence of the Russia. But, Russia in early 90s, \ suffered a deep economic crisis and with internal acute problems its attention to the Central Asian states obviously weakened. Moreover, the leaders of Russia at that time were too keen on the idea of establishing a "strategic partnership" with the West. Therefore, the internal problems and weakening of economic opportunities have prevented Russia to compete with other global players that had their interests in Central Asia and started to actively promote them.

In this manner, at the end of the XX - beginning of the XXI centuries, Central Asia became an arena of active geopolitical and geo-economic competition of world powers. In contrast to the XIX century, when the troops were sent to the region, now the investments are allocated. Investors struggle for access to energy resources of the region, particular direction of oil and gas pipelines, market outlets, foreign policy and foreign economic orientation of the Central Asian countries.

Following independence in 1991 and entry to the UN, the young Central Asian countries became sovereign international entities. Having obtained the opportunity of selection of its own development path, the sovereign states were actively involved in global economic ties focusing on strengthening international economic relations with such leading players as the USA, EU and Asia Pacific region.

Energy, primarily Kazakhstani oil and Turkmenistani gas, is one of the most important factors determining the new geopolitical role of the region. Even today, with construction of oil and gas pipelines in the western and eastern areas, the economic, energy and transport role of Central Asia demonstrates a growth. The USA, European countries, China, Russia, oil and gas companies being the core investors play a major role in the energy sector of Central Asia.

The location at the junction of the Eurasian railways is another important factor of the regional attractiveness. Through Iran, it has an access to the Persian Gulf, through Afghanistan and Pakistan to the Indian Ocean, through China to the Asia-Pacific region.

After implementation of the project "New Great Silk Road", commissioning of the Trans-Asian railway main line, international vehicle road corridor "Western Europe - Western China", development of air traffic, appearance in the future of additional export oil and gas pipelines, the geopolitical and geo-economic importance of Central Asia will be enhanced since the Region will face heavy traffic flows from East to West from the Asia-Pacific region to Europe and Western Asia and back.

In this context, the world powers more and more clearly define the contours of geopolitical and geo-economic interests in the region and strongly are seeking to spread and firmly fix their influence in Central Asia.

\section{Conclusion}

The new geopolitical role of the Central Asian countries as against the former one is determined by the fact that they are very active participants in modern international relations. In the past, the state formations in the region that lost their independence as a result of expansion of the Russian Empire were more the objects than the subjects of the historical process. The diplomacy of the Central Asian countries despite its relative youth is increasingly and confidently cooperating with experienced Russian and Chinese diplomacies with old traditions that have geopolitical interests in the region.

The strategic importance of the region is that it borders two of the five nuclear-weapon states in the world Russia and China and has an access to the Persian Gulf and the Indian Ocean through Iran and Afghanistan.

After implementation of the project "New Great Silk Road", commissioning of the Trans-Asian railway main line, international vehicle road corridor "Western Europe - Western China", development of air traffic, appearance in the future of additional export oil and gas pipelines, the geopolitical and geo-economic importance of Central Asia will be enhanced since the Region will face heavy traffic flows from East to West from the Asia-Pacific region to Europe and Western Asia and back. Since 2015, the Eurasian Economic Union will be launched in the region that implies even greater convergence of the economies of the region with Russia. On the other hand, the European Union is expanding its trade and economic relations with the region as evidenced by the anticipated signing of the Agreement for expanded partnership and cooperation with the Republic of Kazakhstan. Global players are interested in the presence in the region and close cooperation with the Central Asian countries. All this suggests the prospect of further studies on this subject because, since the launch of the Eurasian Economic Union in 2015, many experts predict the end of the multi-vector policy of the Central Asian countries and increasingly close rapprochement with the Russian Federation. 
In this regard, the competition is increasing between major geopolitical players in the region - Russia and China. So, China is basically aimed at preservation of Central Asia as a "strategic rear", expansion of access to hydrocarbon resources in the region, development of infrastructure for transportation of these resources to China and supply of products made in China to markets of Central Asia, Russia and Europe. Russia in turn considers Central Asia as a region that traditionally has been a zone of Russian influence. That is why all of these integration initiatives of Russia such as the Customs Union and the Single Economic Area and the Eurasian Economic Union are aimed at strengthening the Russia's influence and economic presence in the post-Soviet space and in particular in Central Asia.

\section{References}

Agreement for establishment of a single customs area and establishment of the Customs Union. (2007, October 6). Official website of the Commission of the Customs Union. Retrieved November 2, 2014, from http://www.tsouz.ru/Docs/IntAgrmnts/Pages/D_sozdETTiformTS.aspx

Eurasian Economic Community Today. (2013). Official website of the Eurasian Economic Community. Retrieved November 2, 2014, from http://www.evrazes.com/i/data/item7621-1.pdf

Laumulin, M. (2012). Actual Problems of Geopolitical Situation around Central Asia. Actual Issues of Safety in Central Asia (p. 113). Kazakhstan, Almaty: Kazakhstan Institute for Strategic Studies.

Lo, B. (2004). The Long Sunset of Strategic Partnership: Russia's Evolving China Policy. International Affairs, $80(2)$.

Lukashenko, A. (2011, October 18). Fate of Our Integration. Izvestiya. P. 1

Nazarbayev, N. (1997). Eurasian Union: Ideas, Practices, Perspectives (p. 480). Fund for Development of Social and Political Sciences.

Nazarbayev, N. (2011, October 26). Eurasian Union: From an Idea to the History of the Future (P. 1). Izvestiya.

Nichol, J. (2007, August 30). Central Asia: Regional Developments and Implications for U.S. Interests (P. 6). Washington DC, CRS Report for Congress.

Norling, N. (2007). China and Russia: Partners with Tensions. Central Asia-Caucasus Institute. Retrieved November 6, 2014, from file://C:/Users/w/Downloads/Norling_China_and_Russia.pdf

Pan, E. (2006, April 5). Backgrounder: Sino-Russian Energy Ties. Council on Foreign Relations. Retrieved November 7, 2014, from http://www.cfr.org/publication/10363/sinorussian_energy_ties.html

Putin, V. (2011, October 4). New Integration Project for Eurasia - a Future Born Today (P. 1). Izvestiya.

Syroezhkin, K. (2013). Eurasian Space and Chinese Factor. Integration Processes in Eurasia and Modern World (p. 160). Almaty, Kazakhstan: Kazakhstan Institute for Strategic Studies.

The leaders of Eurasian Economic Community gathered in Moscow to discuss the measures to establish the Single Economic Area. (2010, December 9). Official website of NTV.RU. Retrieved November 5, 2014, from http://www.ntv.ru/novosti/212964

Troush, S. (2006). China and Russia in Central Asia: Interests and Tendencies. In R. Azizian, \& E. V. W. Davis (Eds.), Islam, Oil, and Geopolitics in Central Asia after September 11 (p. 220). Rowman \& Littlefield.

Umbach, F. (2004). The Wounded Bear and the Rising Dragon: The Sino-Russian Relationship at the Beginning of the 21st Century, A View from Europe. Asia Europe Journal, 2(1), 43-62.

Wishnick, E. (2005, August 18). Brothers in Arms Again? Assessing the Sino-Russian military exercises (No. 35). PacNet.

\section{Copyrights}

Copyright for this article is retained by the author(s), with first publication rights granted to the journal.

This is an open-access article distributed under the terms and conditions of the Creative Commons Attribution license (http://creativecommons.org/licenses/by/3.0/). 